DOI: $10.15193 /$ zntj/2018/117/266

\author{
ADAM FLORKIEWICZ, MAŁGORZATA BĄCZKOWICZ, \\ SŁAWOMIR PIETRZYK
}

\title{
JAKOŚĆ SENSORYCZNA WARZYW KAPUSTNYCH GOTOWANYCH METODĄ SOUS-VIDE ORAZ TRADYCYJNYMI TECHNIKAMI OBRÓBKI HYDROTERMICZNEJ
}

\begin{abstract}
Streszczenie
Cechy sensoryczne warzyw kapustnych są znaczącym wyróżnikiem dla konsumentów. Charakterystyczny gorzki posmak tych warzyw wynika głównie z obecności glukozynolanów i jest uważany za podstawową przeszkodę w ich akceptacji. Wiadomo jednak, że sposób przygotowania warzyw do spożycia może w istotnym stopniu wpłynąć na ich cechy sensoryczne.

Celem pracy była ocena sensoryczna czterech gatunków warzyw kapustnych, takich jak: brokuły, kalafior o róży białej, kalafior typu Romanesco i kapusta brukselska, poddanych zróżnicowanej obróbce hydrotermicznej - gotowaniu tradycyjnemu, parowaniu i technice sous-vide. Bezpośrednio po obróbce termicznej warzywa były oceniane sensorycznie $\mathrm{z}$ zastosowaniem metod: skalowania (metody 5-punktowej i 9-stopniowej skali hedonicznej), szeregowania do ustalenia preferencji oraz opisowej profilowania sensorycznego z użyciem skali ustrukturowanej. Dodatkowo przeprowadzono instrumentalny pomiar barwy warzyw. W ocenie przeprowadzonej metodą skalowania przy użyciu skali 5-punktowej nie wykazano istotnego zróżnicowania analizowanych cech sensorycznych w zależności od metody obróbki termicznej. Na podstawie wyników oceny sensorycznej według 9-stopniowej skali hedonicznej stwierdzono, że kalafior, brokuł oraz brukselka przygotowane do spożycia metodą parowania i gotowania metodą sous-vide charakteryzują się wyższą jakością sensoryczną niż tradycyjnie gotowane w wodzie. Ocena przeprowadzona metodą opisową profilowania sensorycznego z użyciem skali ustrukturowanej umożliwiła wykazanie, że tekstura zarówno warzyw gotowanych metodą sous-vide, jak i parowanych była wyżej oceniana niż gotowanych tradycyjnie. Jak wykazano na podstawie instrumentalnego pomiaru barwy i obliczonej na tej podstawie wartości $\Delta \mathrm{E}$, barwa warzyw przygotowanych metodą sous-vide była najbardziej zbliżona do barwy warzyw surowych.
\end{abstract}

Słowa kluczowe: warzywa kapustne, sous-vide, parowanie, gotowanie w wodzie, jakość sensoryczna

Dr inż. A. Florkiewicz, dr hab. inż. S. Pietrzyk, Katedra Analizy i Oceny Jakości Żywności, dr inż. M. Baczkowicz, Katedra Technologii Gastronomicznej i Konsumpcji, Wydz. Technologii Żywności, Uniwersytet Rolniczy w Krakowie, ul. Balicka 122, 30-149 Kraków.

Kontakt: adam.florkiewicz@urk.edu.pl 


\section{Wprowadzenie}

Warzywa odgrywają istotną rolę w żywieniu człowieka, są bogatym źródłem witamin, składników mineralnych, błonnika pokarmowego i związków fitochemicznych [28]. Spożywanie tych produktów korzystnie wpływa na zdrowie człowieka poprzez poprawę funkcjonowania układu pokarmowego czy zmniejszanie ryzyka chorób przewlekłych, takich jak choroby serca, cukrzyca i niektóre formy nowotworów.

Cechy sensoryczne warzyw kapustnych są znaczącym wyróżnikiem dla konsumentów [6]. Jest to szczególnie istotne w przypadku dzieci, które przede wszystkim kierują się preferencjami sensorycznymi przy wyborze żywności [1,27] i nie są podatne na komunikaty zdrowotne [31]. U ludzi występuje wrodzona skłonność do wyboru produktów o smaku słodkim i niechęć - do gorzkich [30]. Warzywa kapustne, takie jak: kapusta, brokuły, kalafior, brukselka, jarmuż czy kapusta pekińska są bogatym źródłem glukozynolanów (GLS). Charakterystyczny gorzki smak tych warzyw jest związany głównie z obecnością GLS [5] i jest uważany za czynnik ograniczający ich akceptowalność $[6,7]$. Równocześnie silne właściwości antykancerogenne produktów rozpadu GLS stanowią ważną przesłankę do większego spożycia warzyw kapustnych w kontekście profilaktyki chorób nowotworowych [8].

Warzywa często nie są spożywane w postaci surowej, ale są np. gotowane w wodzie, na parze lub smażone. Niekiedy łączy się je z innymi składnikami przed spożyciem. Sposób przygotowywania warzyw wpływa nie tylko na ich skład chemiczny, ale także na cechy sensoryczne. Warzywa, które są gotowane tradycyjnie, gotowane na parze lub poddawane działaniu mikrofal tracą składniki odżywcze, ponieważ ściany komórkowe ulegają uszkodzeniu w wyniku działania wysokiej temperatury, co przyczynia się do wypłukiwania składników odżywczych z komórek [2]. Metoda sous-vide staje się coraz bardziej popularną formą obróbki termicznej żywności. Pozwala ona na tworzenie potraw o unikatowych właściwościach sensorycznych, a ponadto ogranicza straty wielu składników odżywczych [9]. Metoda sous-vide korzystniej wpływa także na teksturę warzyw w porównaniu z gotowaniem tradycyjnym. Jak sugeruje Baldwin [2], wyższa retencja składników odżywczych może zintensyfikować smak, co w konsekwencji spowoduje, że stanie się on w przypadku niektórych warzyw zbyt wyraźny dla konsumentów. W dostępnej literaturze nieliczne prace dotyczą wpływu gotowania w niskiej temperaturze i w opakowaniu próżniowym na jakość sensoryczną różnych warzyw kapustnych.

Celem pracy była ocena sensoryczna czterech wybranych warzyw kapustnych (Brassica) poddanych obróbce sous-vide $\mathrm{w}$ porównaniu $\mathrm{z}$ warzywami gotowanymi tradycyjnie w wodzie lub na parze. 


\section{Material i metody badań}

Badany materiał stanowiły cztery gatunki warzyw kapustnych: brokuły, kalafior o róży białej, kalafior typu Romanesco i kapusta brukselska. Warzywa (5 kg świeżej masy każdego) myto, osuszano i krojono na cztery lub osiem części (za wyjątkiem kapusty brukselskiej). Tak przygotowany materiał dzielono na trzy części i poddawano obróbce cieplnej: gotowaniu metodą sous-vide, gotowaniu tradycyjnemu i parowaniu. Bezpośrednio po obróbce termicznej warzywa były poddawane ocenie sensorycznej.

Warzywa przed gotowaniem metodą sous-vide zapakowano próżniowo (urządzenie do pakowania próżniowego VBN-4, RM Gastro, Czechy), a następnie gotowano w temp. $90{ }^{\circ} \mathrm{C}$ przez ok. 45 - 50 min metodą sous-vide (model 225448 , Hendi, Niemcy). Gotowanie tradycyjne w wodzie destylowanej przez ok. 10 - 15 min prowadzono na trzonie elektrycznym indukcyjnym przy zachowaniu proporcji surowca do wody $1: 3$ (m : v) (Kuchnia indukcyjna, Hendi, Niemcy). Parowanie warzyw prowadzono z wykorzystaniem pieca Combi-Steam (model 225 547, Hendi, Niemcy) w temp. $100{ }^{\circ} \mathrm{C}$ przez $7 \mathrm{~min}$.

Analizę sensoryczną przeprowadzano w laboratorium sensorycznym, spełniającym standardy PN-EN ISO 8589:2010 [22]. W ocenie wziął udział 14-osobowy panel sprawdzony pod względem wrażliwości sensorycznej zgodnie z normą PN-ISO 3972:1998 [21] i przeszkolony do oceny badanych produktów. Każdą zakodowaną próbkę poddawano ocenie sensorycznej metodami:

- skalowania według PN-ISO 4121:1998 [23] - metodą 5-punktową;

Jako charakterystyczne i istotne dla jakości sensorycznej warzyw wybrano cechy, którym przypisano i zdefiniowano 5 poziomów jakości: 5 - jakość najwyższa, bardzo dobra do 1 - jakość najniższa, niedostateczna. Poszczególnym cechom jakościowym przyporządkowano współczynniki ważkości odpowiednio: wygląd ogólny - 0,1, barwa - 0,1, tekstura oceniana $\mathrm{z}$ użyciem sztućców (twardość $-0,1$ ), tekstura oceniana w jamie ustnej (twardość - 0,05, kruchość - 0,05, spoistość 0,05 , wilgotność - 0,05), zapach - 0,2, smak - 0,2 i dodatkowo słoność - 0,1. Procedura postępowania podczas oceny cech była każdorazowo dołączana do karty ocen. Na podstawie spostrzeżeń i podanych określeń słownych oceniający oceniali każdy wyróżnik jakościowy warzywa w skali 1 - 5, następnie oceny te mnożono przez odpowiednie współczynniki ważkości, a oceny cząstkowe sumowano i uzyskiwano ocenę końcową jakości sensorycznej badanego produktu.

- skalowania - metodą 9-stopniowej skali hedonicznej [23];

Każdy produkt był oceniany według 9-stopniowej skali pożądalności (od 1 - bardzo nie lubię do 9 - bardzo lubię).

- szeregowania do ustalenia preferencji - zgodnie z ISO 8587:2006 [15];

W celu określenia preferencji z uwagi na sposób termicznej obróbki każdego z warzyw zastosowano metodę szeregowania. Zadaniem oceniających było uszerego- 
wanie próbek każdego warzywa pod względem najkorzystniejszej (z uwagi na jakość sensoryczną) metody jego gotowania.

- opisową profilowania sensorycznego $-\mathrm{z}$ zastosowaniem skali ustrukturowanej według PN-EN ISO 13299:2016-05 [24].

W celu określenia profilu sensorycznego każdego z badanych warzyw, przed przystąpieniem do właściwej oceny, lider zespołu i oceniający dobrali metodą konsensusu charakterystyczne cechy, których natężenie określano w postaci skali trzy-, cztery- lub pięciostopniowej dwukierunkowej (np. słoność: niesłony, lekko za mało słony, w sam raz słony, lekko za słony, bardzo za słony). Wybrane cechy były zbieżne z cechami ocenianymi metodą 5-punktową. Oceniający poprzez zaznaczenie na skali wyrażali natężenie i stopień akceptacji każdej cechy.

Pomiar barwy prowadzono w systemie CIE L*a*b* za pomocą spektrofotometru Konica Minolta CM-3600d (Minolta Corp., Ramsey, USA). Oznaczenie wykonywano w świetle odbitym, z użyciem obserwatora $10^{\circ}$ i iluminantu D65. W celu oceny różnic barwy warzyw obliczano całkowitą różnicę barw $(\Delta \mathrm{E})$. Z każdej próby wykonano dziesięć pomiarów.

Analizę statystyczną skalowania 5-punktowego przeprowadzono uogólnionym testem Stuarta-Maxwella [3]. Obliczenia przeprowadzono przy użyciu oprogramowania napisanego na potrzeby tej pracy w języku Python. Wszystkie obliczenia wykonano na poziomie istotności $\mathrm{p}<0,05$. Wyniki dotyczące pozostałych metod oceny sensorycznej oraz instrumentalnego pomiaru barwy poddano dwuczynnikowej analizie wariancji (czynnik pierwszy: gatunek warzyw, czynnik drugi: metoda obróbki). Hipotezę o normalności rozkładu wyników weryfikowano testem Shapiro-Wilka, a jednorodności wariancji - testem Lavene'a. Różnice pomiędzy wartościami średnimi oceniano za pomocą testu NIR Fishera $(\mathrm{p}<0,05)$. Obliczenia wykonano za pomocą pakietu oprogramowania Statistica 10.1 (StatSoft Inc., USA).

\section{Wyniki i dyskusja}

Jakość sensoryczna warzyw kapustnych w większym stopniu wpływa na ich konsumpcję niż wartość odżywcza [16]. W ocenie sensorycznej kalafiora o róży białej przeprowadzonej przy użyciu skali 5-punktowej oceniający przyznali wyższe noty warzywu parowanemu. Niższe oceny przyznano natomiast kalafiorowi gotowanemu w wodzie (rys. 1).

Po przeanalizowaniu wyników poszczególnych wyróżników jakościowych stwierdzono, że jedynie barwa kalafiora gotowanego w wodzie była nieznacznie wyżej oceniana niż parowanego czy przygotowanego metodą sous-vide $(p>0,05)$. Prawdopodobnie barwa kalafiora gotowanego była najbardziej zbliżona do warzywa surowego. Potwierdzają to wyniki instrumentalnego pomiaru barwy (najniższa wartość $\Delta \mathrm{E}$ ). 


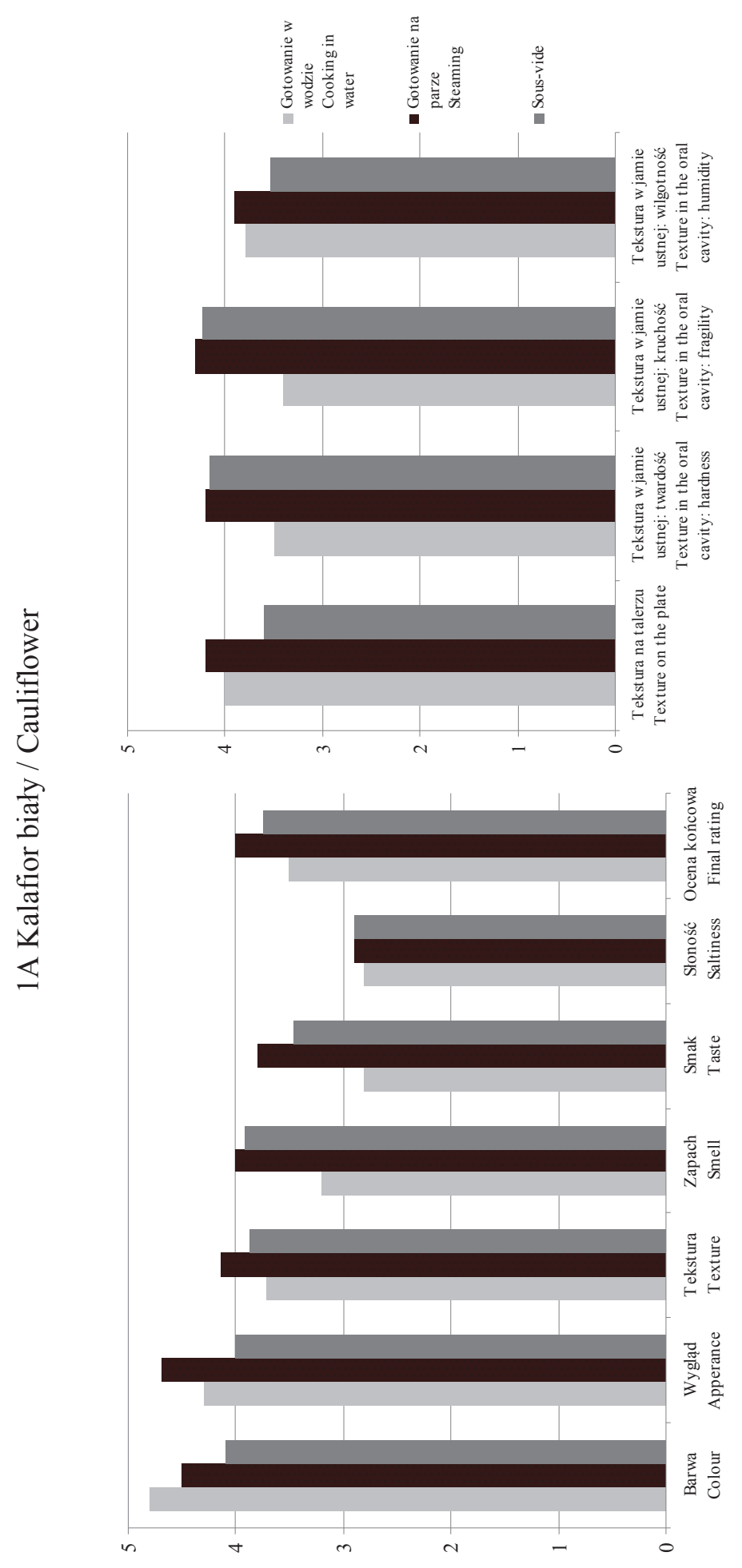




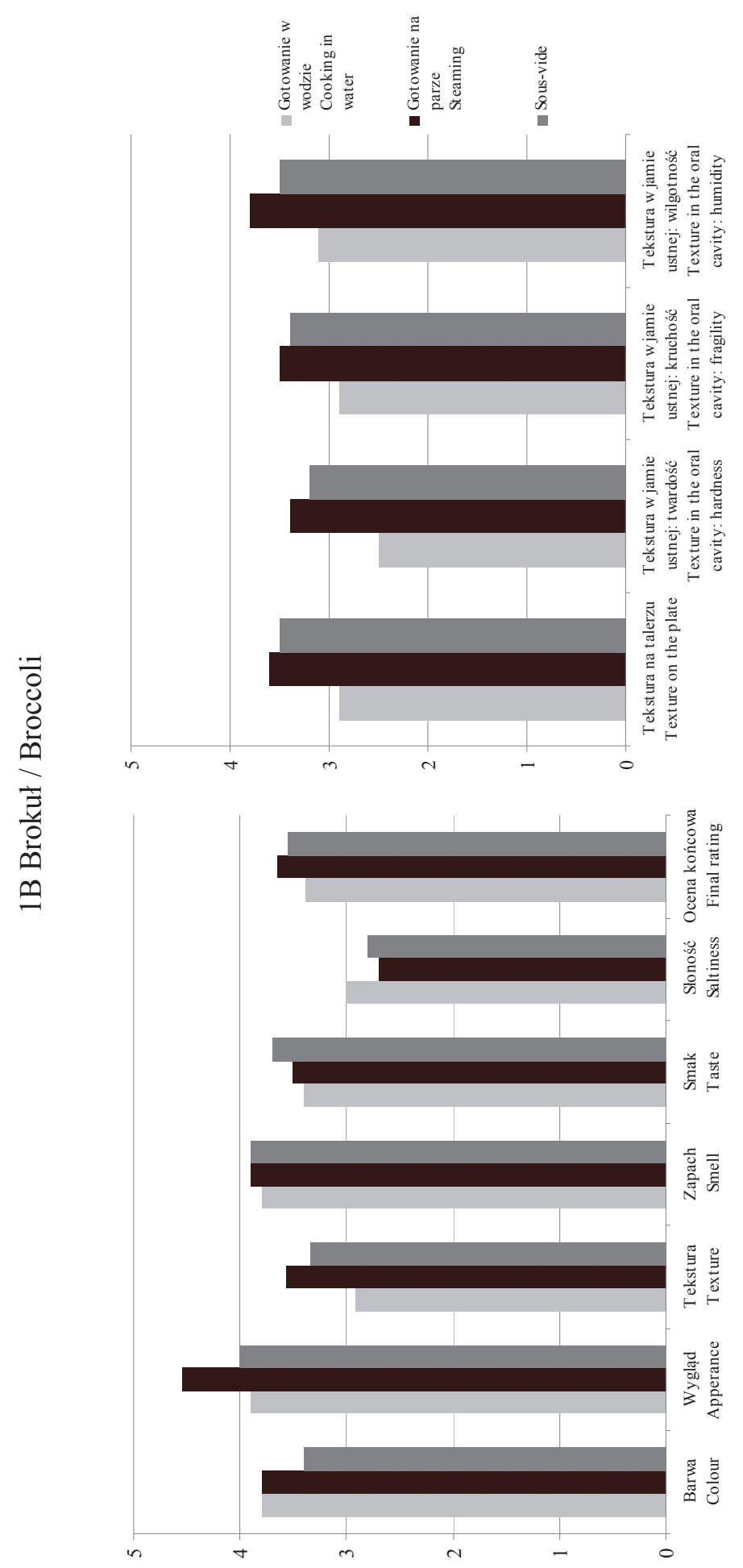




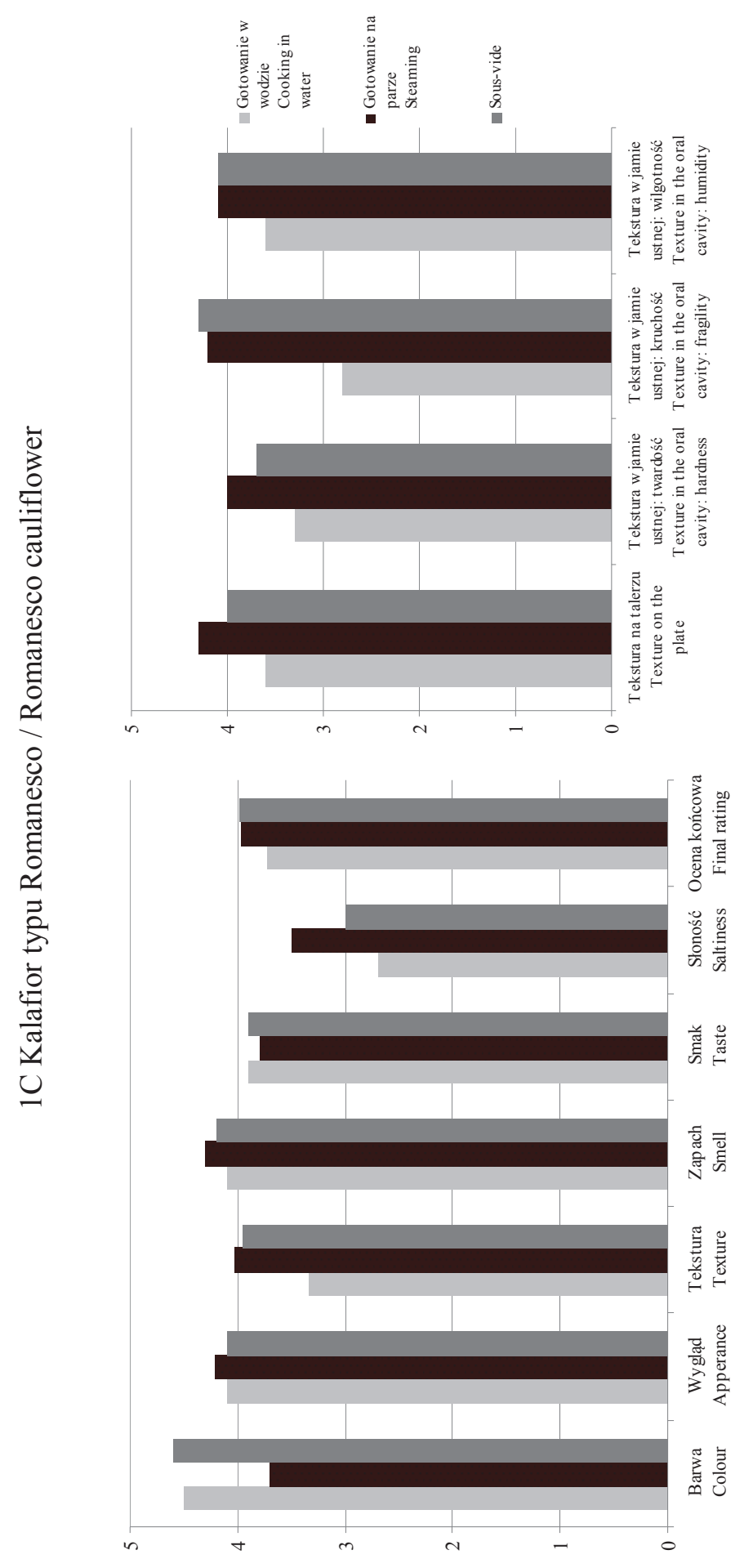




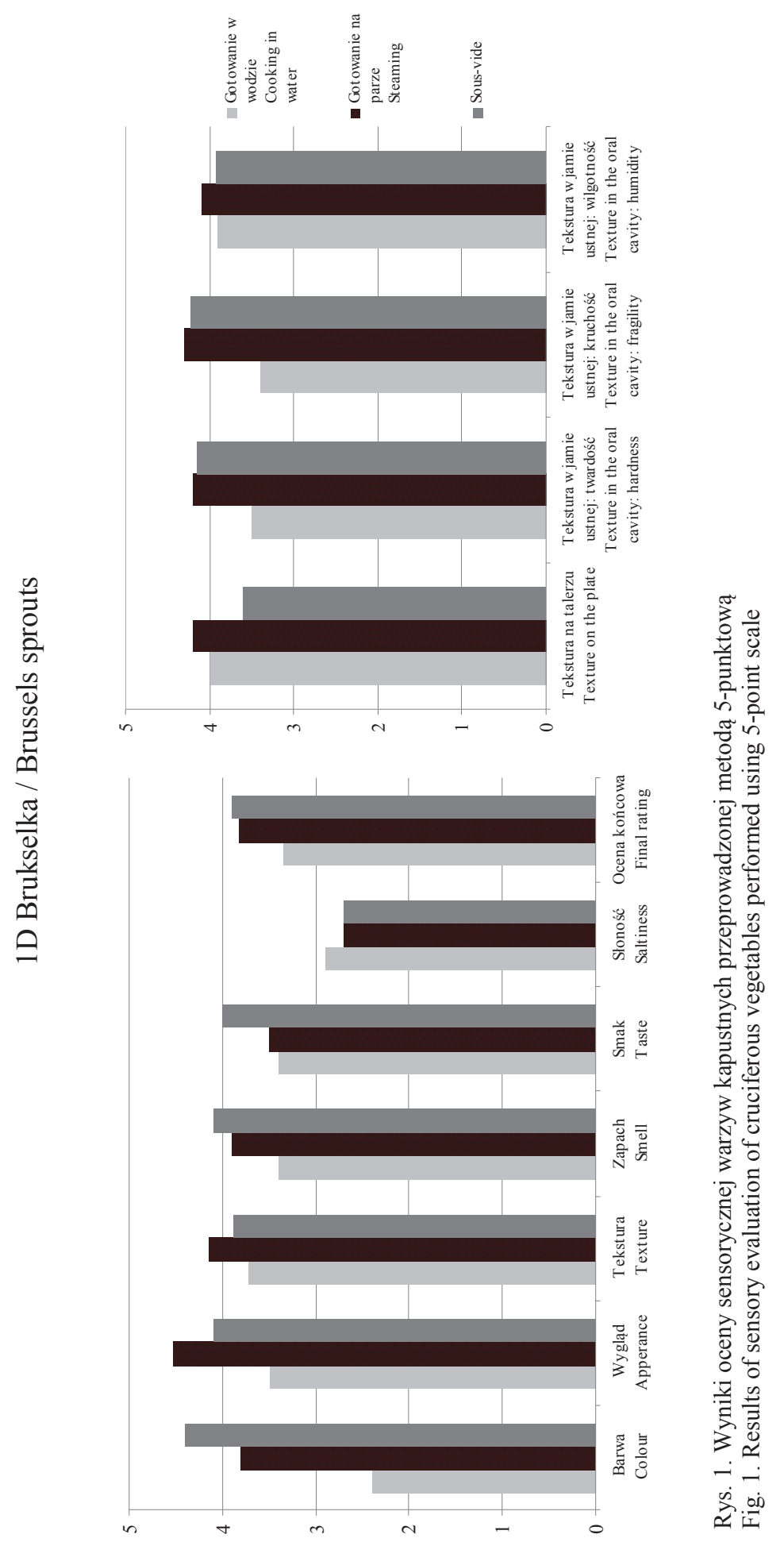


Kalafior gotowany w wodzie odznaczał się istotnie niższymi wartościami wskaźników $\mathrm{L}^{*}$ oraz a* niż warzywo parowane czy gotowane sous-vide (tab. 3). Pod względem tekstury, zapachu, słoności kalafiora parowanego i przygotowywanego metodą sousvide zaobserwowano, że wyniki tych wyróżników były bardzo zbliżone. Podobnątendencję zaobserwowano w przypadku brokułu. W odniesieniu do tego warzywa należy zauważyć, że niższą ocenę za słoność przyznano warzywom gotowanym w wodzie niż parowanym. Z kolei smak brokułu oraz zapach wyżej oceniane były w przypadku warzywa gotowanego metodą sous-vide. Kalafior typu Romanesco i brukselka przygotowane tą metodą oceniono nieznacznie wyżej w stosunku do tych warzyw przygotowanych pozostałymi metodami kulinarnymi. Spośród ocenianych cech sensorycznych kalafior typu Romanesco gotowany metodą sous-vide odznaczał się lepszą teksturą (ocenianą w jamie ustnej) oraz słonością, a brukselka - barwą, zapachem i smakiem niż warzywa gotowane w wodzie. Zdaniem oceniających jakość sensoryczna kalafiora typu Romanesco parowanego oraz przetworzonego metodą sous-vide była zbliżona. Jednocześnie smak i barwa brukselki poddanej obróbce metodą sous-vide były nieznacznie wyżej ocenione, a wygląd zewnętrzny - niżej niż brukselki parowanej. Różnice obserwowane w ocenie przeprowadzonej metodą skalowania przy użyciu skali 5punktowej nie były statystycznie istotne. Otrzymane wyniki charakteryzowały się wysoką jednorodnością w odniesieniu do poszczególnych cech sensorycznych. Rodzaj obróbki nie miał istotnego wpływu na cechy sensoryczne gotowego produktu ocenionego tą metodą.

Wyniki oceny z zastosowaniem 9-stopniowej skali hedonicznej potwierdziły, że przygotowywanie kalafiora, brokułu oraz brukselki poprzez ich parowanie i gotowanie metodą sous-vide pozwala na uzyskanie warzyw o wyższej jakości sensorycznej niż po ich tradycyjnym gotowaniu w wodzie (tab. 1).

Niezależnie od zastosowanej metody obróbki podobne oceny $(\mathrm{p}>0,05)$ przyznano natomiast kalafiorowi typu Romanesco. Zbliżone wyniki w przypadku obróbki termicznej brokułu uzyskano metodą szeregowania. Zdaniem zespołu oceniającego zarówno parowanie, jak i gotowanie metodą sous-vide pozwala na uzyskanie produktu o zbliżonej jakości sensorycznej (tab. 2).

W przypadku pozostałych warzyw oceniający istotnie częściej wskazywali parowanie jako bardziej preferowaną formę obróbki termicznej niż metodę sous-vide. Jednocześnie, niezależnie od rodzaju warzywa, najmniej pożądanym sposobem ich przygotowania było tradycyjne gotowanie $\mathrm{w}$ wodzie $(\mathrm{p}<0,05)$. Jakość sensoryczna warzyw była statystycznie istotnie zróżnicowana jedynie w zależności od zastosowanej metody, natomiast gatunek warzyw nie wpływał istotnie na preferencje. Wyniki badań własnych korespondują z rezultatami innych autorów wskazujących, że warzywa gotowane $\mathrm{w}$ wodzie $\mathrm{w}$ wyniku wypłukiwania rozpuszczalnych związków smakowozapachowych są mniej intensywne w smaku niż warzywa gotowane na parze lub „ba- 
rierowo" [19, 29, 32]. Mogłoby to wyjaśniać przyznawanie wyższych ocen warzywom parowanym i gotowanym metodą sous-vide niż gotowanym tradycyjnie. Tę samą zależność w stosunku do kalafiora i brokułu wykazali także Mansour i wsp. [17].

Interesujących i szczegółowych wyników dotyczących oceny poszczególnych cech jakościowych dostarczyła metoda opisowa profilowania sensorycznego z wykorzystaniem skali ustrukturowanej. Barwa kalafiora parowanego i gotowanego metodą sous-vide była właściwa według odpowiednio: 92,9 i 57,1 \% oceniających (rys. 2). Pozostała część oceniających wskazała, że barwa warzyw poddanych ww. obróbce uległa niewielkim zmianom. Jednocześnie aż 85,7 \% oceniających wskazało, że barwa kalafiora gotowanego tradycyjnie była nieznacznie zmieniona, a tylko według 7,1\%była właściwa. Należy zauważyć, że wyniki te są odmienne od uzyskanych metodą skalowania z użyciem skali 5-punktowej, według której barwa kalafiora gotowanego tradycyjnie była wyżej oceniona od parowanego i przygotowanego metodą sous-vide. Tradycyjna metoda gotowania była natomiast korzystna w przypadku gotowania brukselki. Ponad połowa oceniających wskazała, że barwa warzywa tak przygotowanego jest właściwa. W ocenie barwy brukselki przygotowanej różnymi metodami można zauważyć, że równie korzystną formą obróbki była technika sous-vide. Według 46,2 \% oceniających barwa ta była właściwa lub nieznacznie zmieniona. Jednocześnie parowanie brukselki wpłynęło najbardziej niekorzystnie na barwę warzywa. Ponad $20 \%$ oceniających określiło ją jako mocno zmienioną. Parowanie z kolei dawało najlepsze

Tabela 1. Wyniki oceny pożądalności warzyw kapustnych w 9-stopniowej skali hedonicznej

Table 1. Results of desirability evaluation of cruciferous vegetables in 9-point hedonic scale

\begin{tabular}{|c|c|c|c|c|c|c|c|c|c|}
\hline \multirow{3}{*}{$\begin{array}{l}\text { Warzywa } \\
\text { (czynnik A) } \\
\text { Vegetables } \\
\text { (factor A) }\end{array}$} & \multicolumn{6}{|c|}{$\begin{array}{c}\text { Proces termiczny (czynnik B) } \\
\text { Thermal process (factor B) }\end{array}$} & \multirow{2}{*}{\multicolumn{3}{|c|}{$\begin{array}{c}\text { Wyniki analizy } \\
\text { wariancji } \\
\text { Results of } \\
\text { variance analysis }\end{array}$}} \\
\hline & \multicolumn{2}{|c|}{$\begin{array}{c}\text { Gotowanie } \\
\text { w wodzie } \\
\text { Cooking in water }\end{array}$} & \multicolumn{2}{|c|}{$\begin{array}{c}\text { Gotowanie na parze } \\
\text { Steaming }\end{array}$} & \multicolumn{2}{|c|}{$\begin{array}{c}\text { Gotowanie } \\
\text { sous-vide } \\
\text { Sous-vide cooking }\end{array}$} & & & \\
\hline & $\begin{array}{l}\text { Średnia } \\
\text { Mean }\end{array}$ & $\begin{array}{l}\text { Mediana } \\
\text { Median }\end{array}$ & $\begin{array}{c}\text { Średnia } \\
\text { Mean }\end{array}$ & $\begin{array}{l}\text { Mediana } \\
\text { Median }\end{array}$ & $\begin{array}{l}\text { Średnia } \\
\text { Mean }\end{array}$ & $\begin{array}{l}\text { Mediana } \\
\text { Median }\end{array}$ & A & B & $\mathrm{A} \times \mathrm{B}$ \\
\hline $\begin{array}{l}\text { Kalafior biały } \\
\text { Cauliflower }\end{array}$ & $3,86^{\mathrm{a}}$ & 3 & $6,07^{\mathrm{c}}$ & 6 & $5,79^{\mathrm{c}}$ & 6 & & & \\
\hline Brokuł / Broccoli & $3,14^{\mathrm{a}}$ & 3 & $5,46^{\mathrm{c}}$ & 6 & $5,14^{\mathrm{bc}}$ & 6 & & & \\
\hline $\begin{array}{c}\text { Kalafior typu } \\
\text { Romanesco } \\
\text { Romanesco } \\
\text { cauliflower }\end{array}$ & $5,36^{\mathrm{c}}$ & 6 & $5,71^{\mathrm{c}}$ & 6 & $6,21^{\mathrm{c}}$ & 7 & 0,01 & 0,00 & 0,00 \\
\hline $\begin{array}{c}\text { Brukselka } \\
\text { Brussels sprouts }\end{array}$ & $4,07^{\mathrm{ab}}$ & 4 & $6,07^{\mathrm{c}}$ & 6 & $5,29^{\mathrm{bc}}$ & 5 & & & \\
\hline
\end{tabular}

Objaśnienia / Explanatory notes:

$\mathrm{a}, \mathrm{b}, \mathrm{c}$ - wartości średnie $\mathrm{w}$ wierszach oznaczone różnymi literami różną się statystycznie istotnie $(\mathrm{p} \leq 0,05) /$ mean values in rows denoted by different letters differ statistically significantly $(\mathrm{p} \leq 0.05)$. 


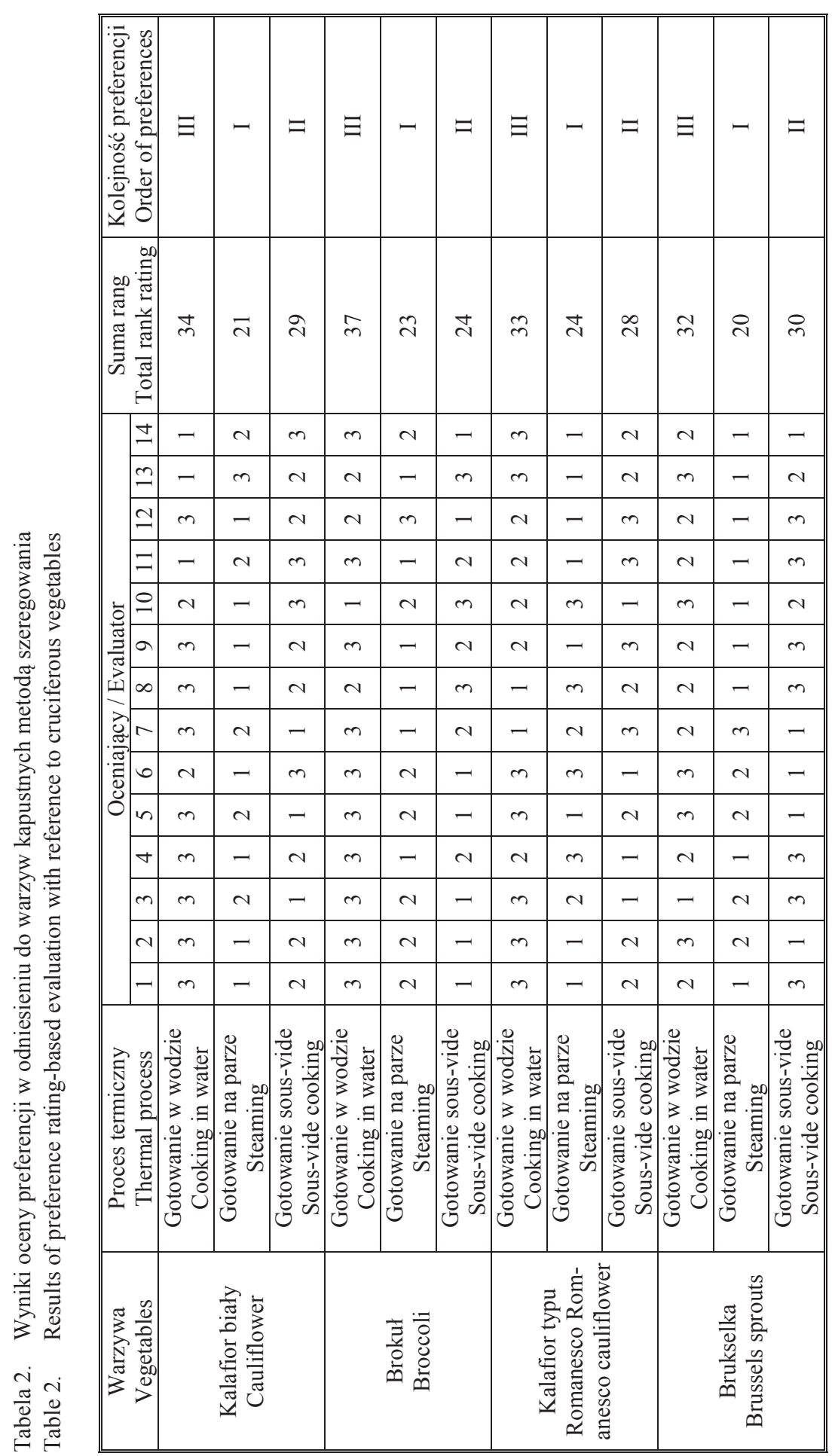




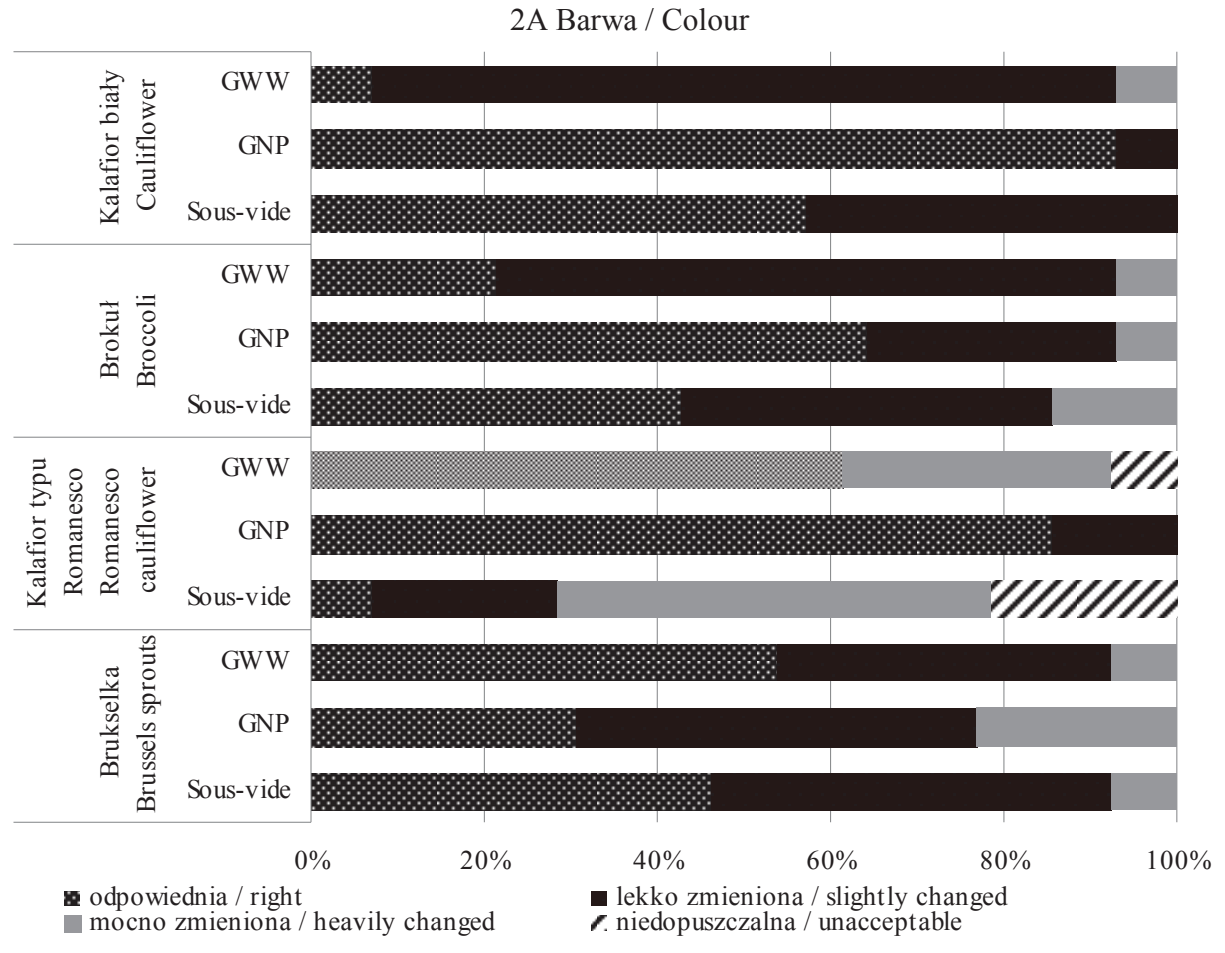

2B Wygląd / Appearance

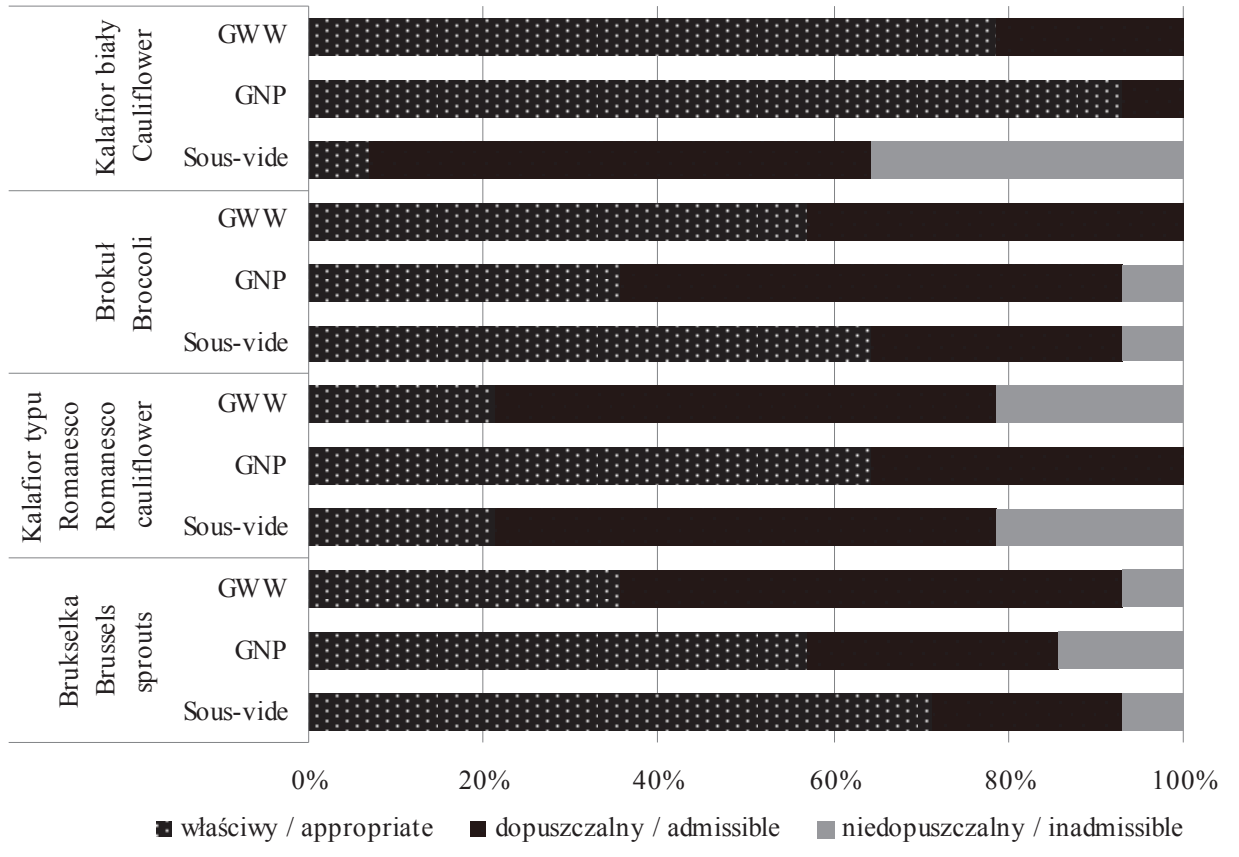




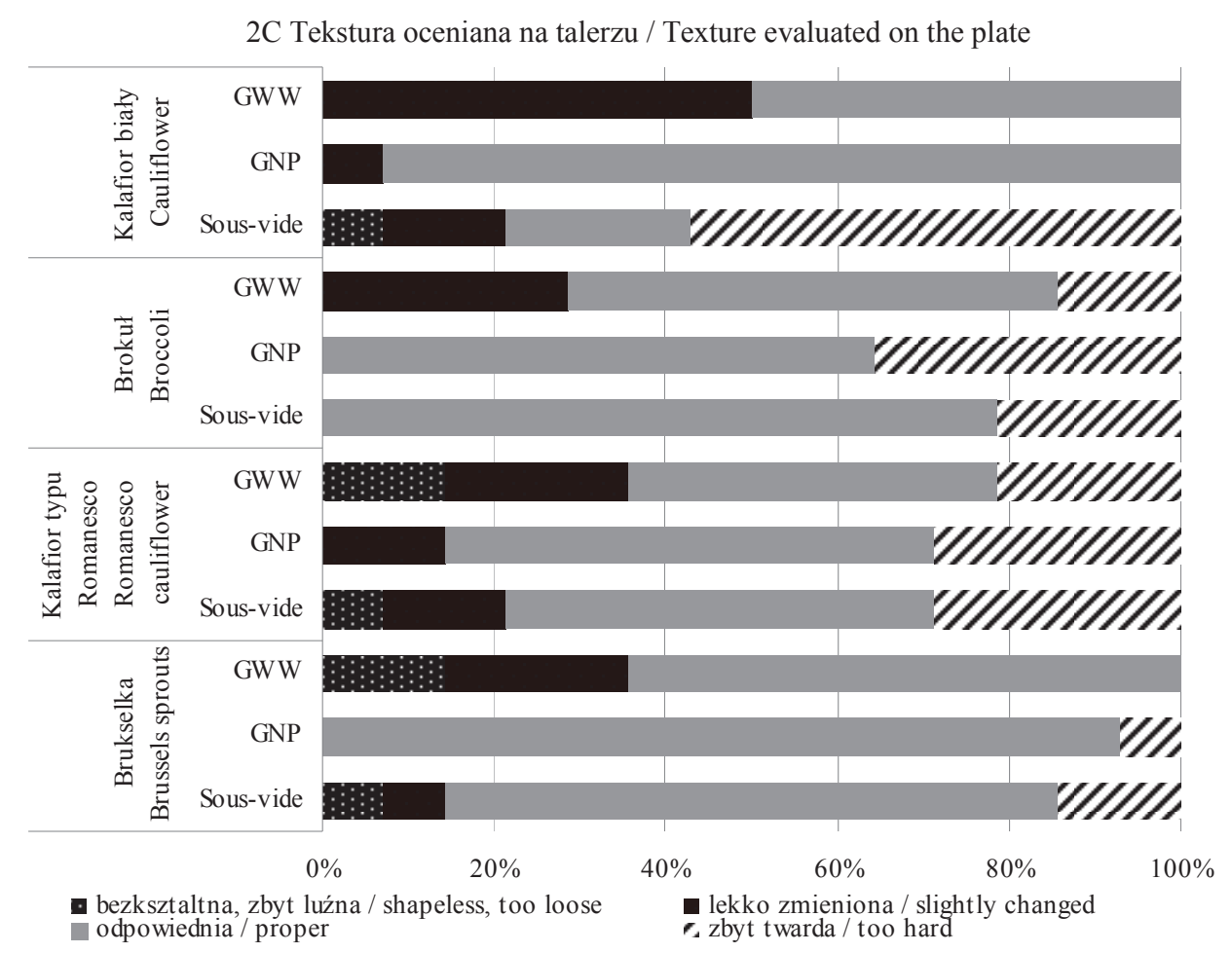

2D Tekstura oceniana w jamie ustnej: twardość / Texture evaluated in the oral cavity: hardness

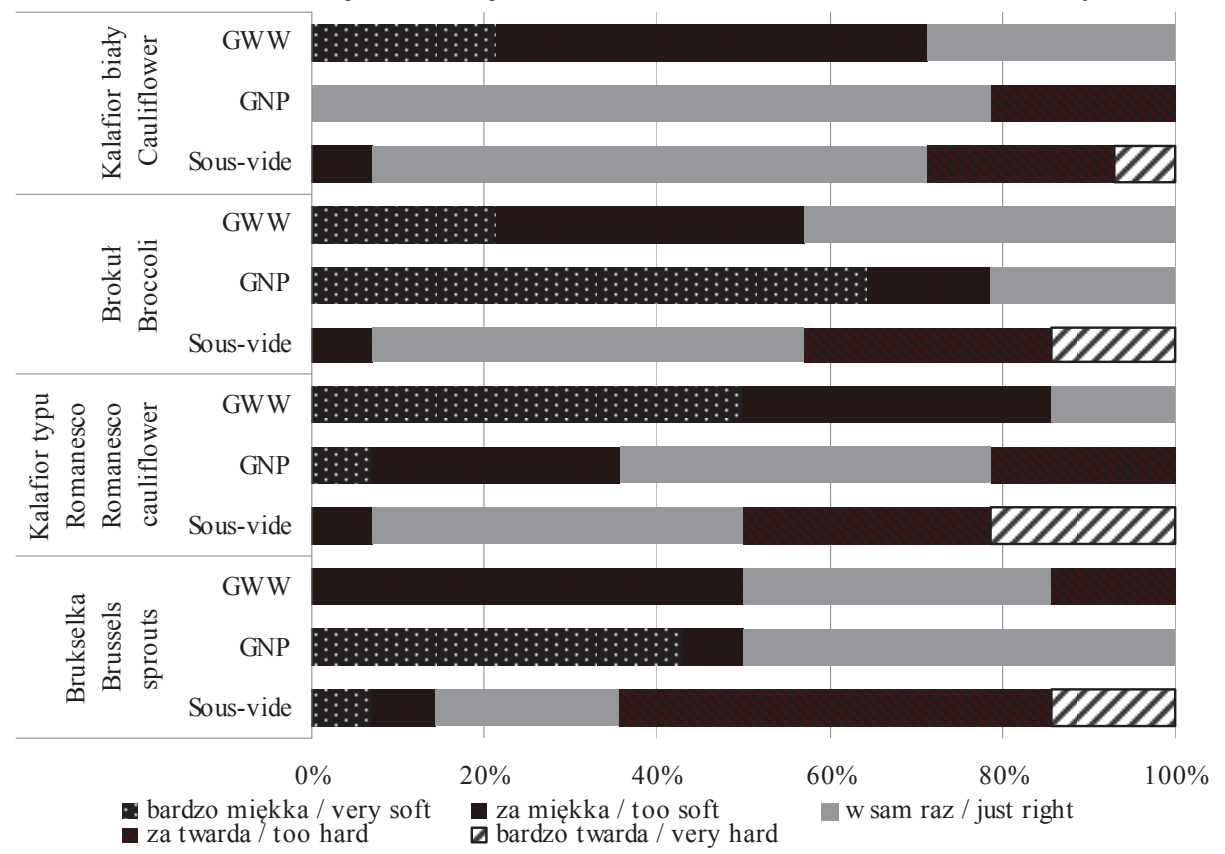


2E Tekstura oceniana w jamie ustnej: wilgotność / Texture evaluated in the oral cavity: humidity

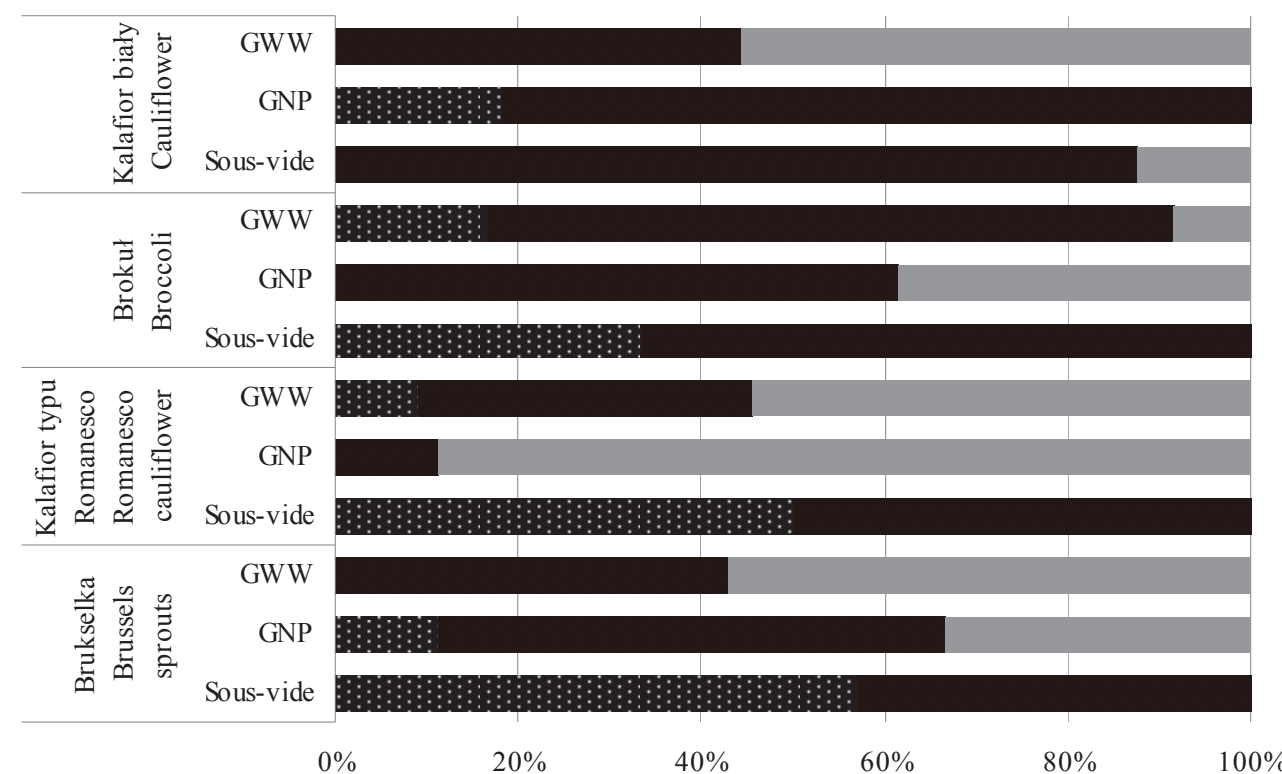

zbyt sucha / too dry a odpowiednia / proper_abyt wodnista / too watery

2F Tekstura oceniana w jamie ustnej: kruchość / Texture evaluated in the oral cavity: fragility

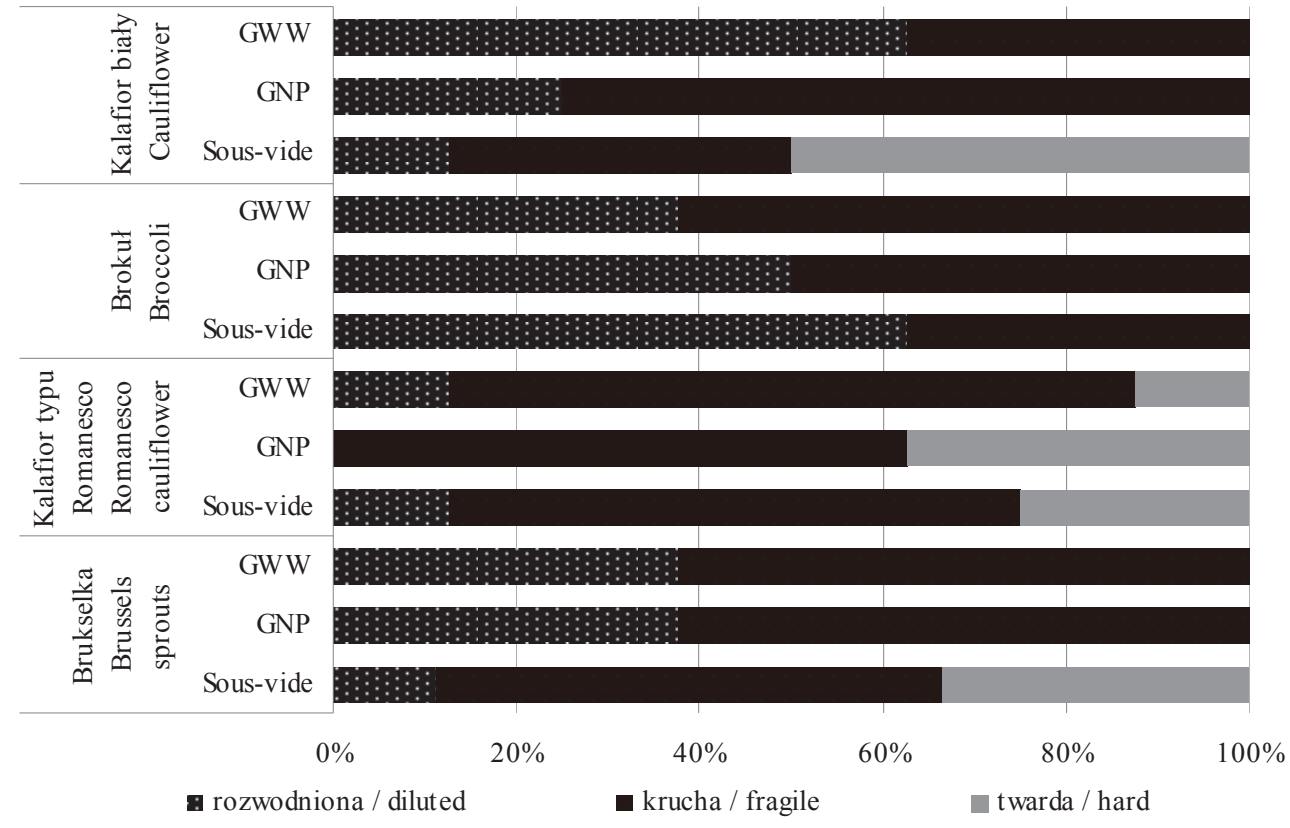




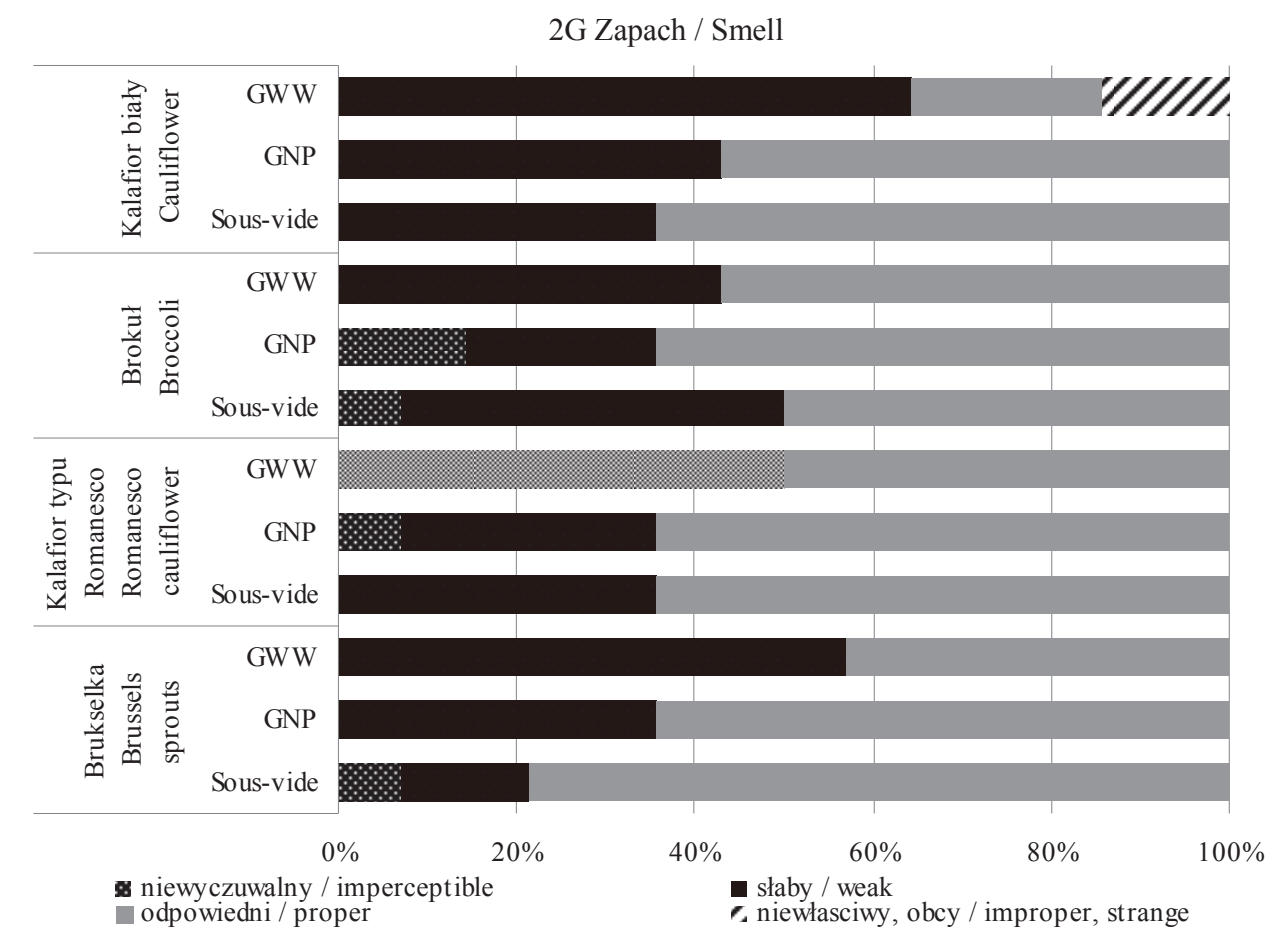

2H Smak / Taste

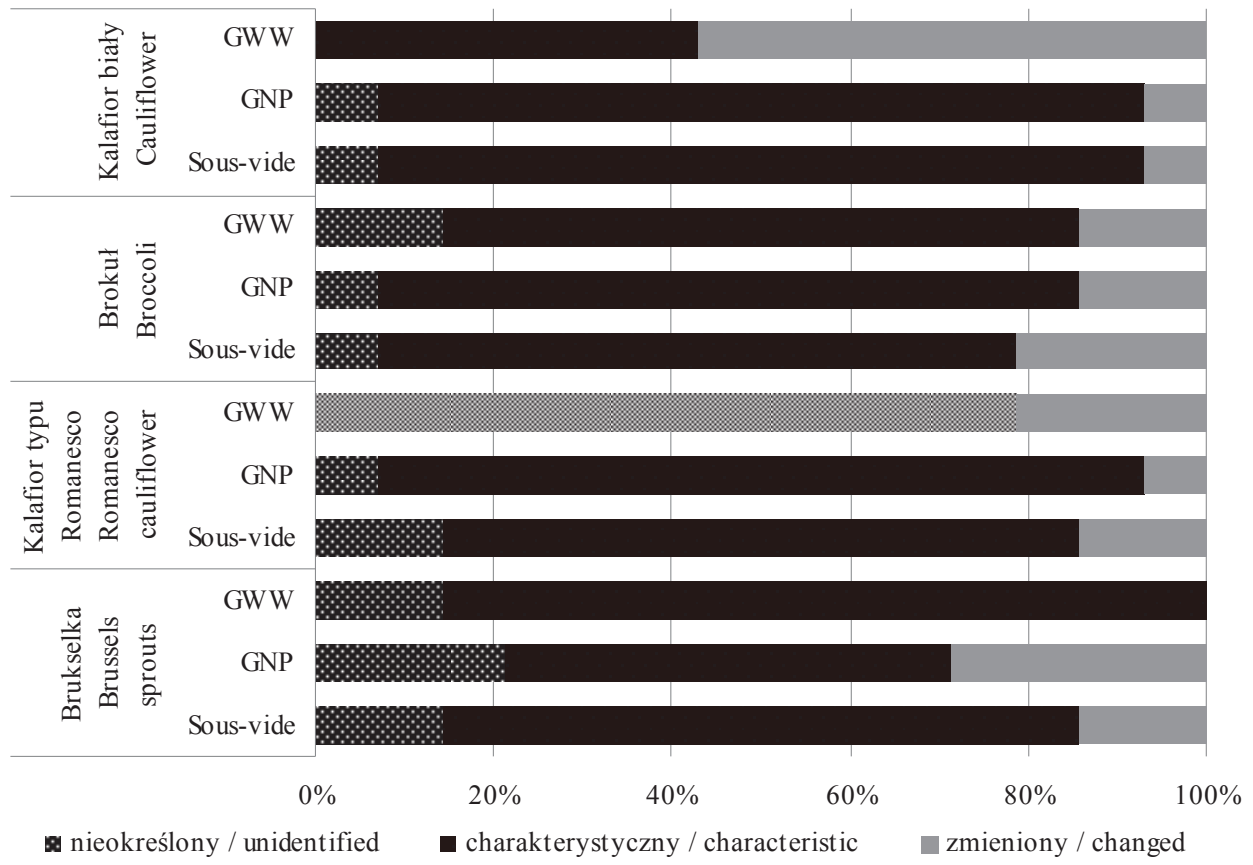


2I Słoność / Saltiness

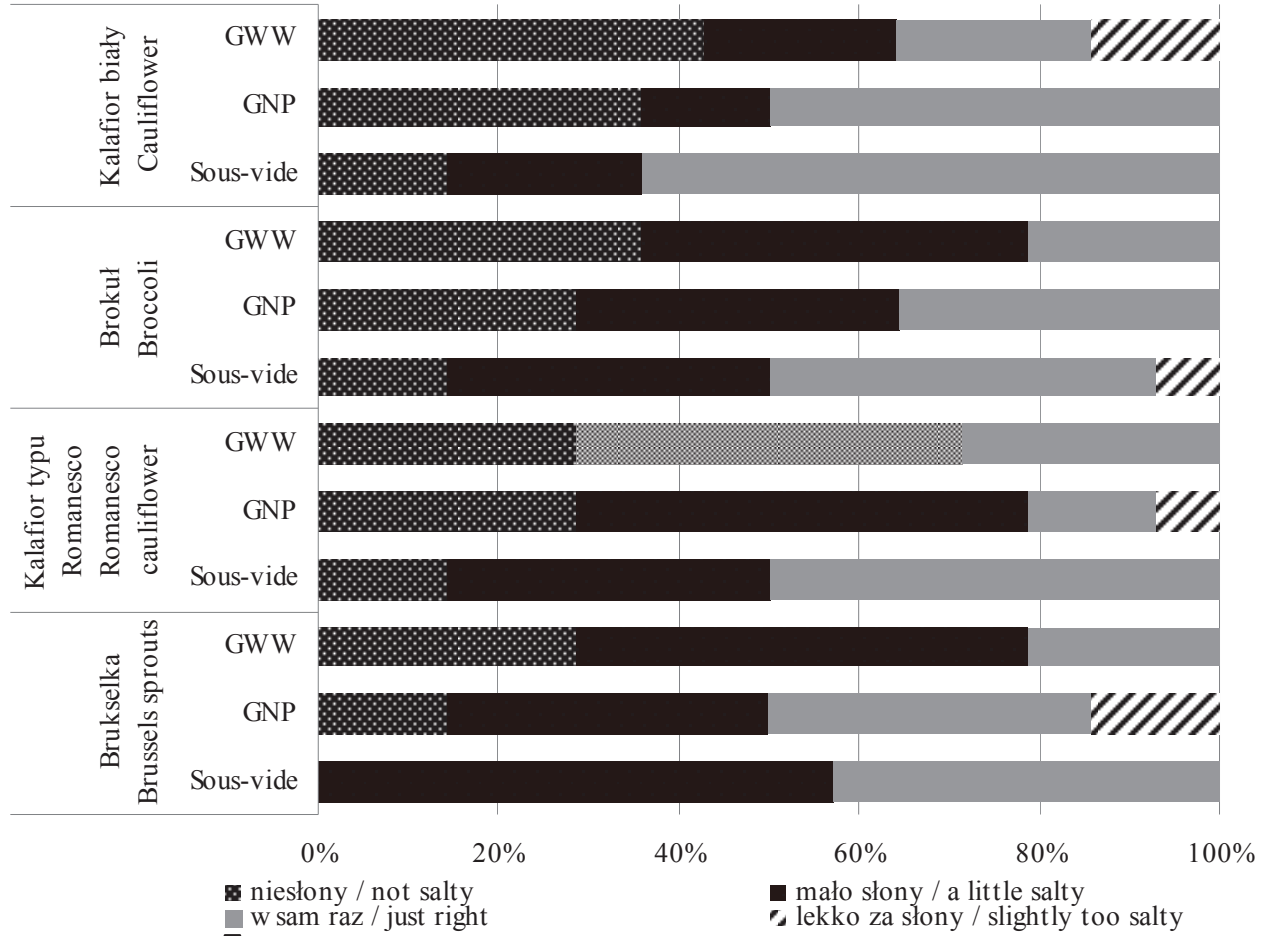

Objaśnienia / Explanatory notes:

GWW - Gotowanie w wodzie / Cooking in water; GNP - Gotowanie na parze / Steaming

Rys. 2. Wyniki oceny opisowego profilowania sensorycznego warzyw kapustnych z wykorzystaniem skali ustrukturowanej

Fig. 2. Evaluation results of descriptive sensory profiling of cruciferous vegetables using structured scale

rezultaty w przypadku brokułu. Zdaniem zdecydowanej większości oceniających barwa tak przygotowanego warzywa była właściwa. Po przeanalizowaniu wyników dotyczących oceny tej cechy jakościowej można zauważyć, że metoda sous-vide w sposób niekorzystny wpłynęła na barwę kalafiora typu Romanesco. Ponad jedna czwarta oceniających uznała, że była ona nie do zaakceptowania. Brukselka i brokuł przygotowane metodą sous-vide odznaczały się właściwym (odpowiednio: 71,4 i 64,3 \%) lub dopuszczalnym wyglądem (21,4 i $28,6 \%$ ). W przypadku pozostałych technik oceny były niższe. Z kolei najkorzystniejszą pod względem wyglądu warzyw formą obróbki termicznej kalafiora typu Romanesco było parowanie (według 64,3 \% oceniających), kalafiora o róży białej - parowanie lub gotowanie w wodzie (odpowiednio 92,9 i 78,6 \%), a brokułu - sous-vide (64,3\%). Zmian barwy warzyw kapustnych, będących wynikiem obróbki hydrotermicznej, dowodzą wyniki uzyskane przez innych autorów 
$[18,25,33]$, przy czym nie można wskazać jednoznacznej tendencji zmian. Dla przykładu Martinez-Hernandez i wsp. [18] wykazali, że o ile gotowanie brokułu metodą sous-vide powoduje pojaśnienie barwy, to gotowanie tego warzywa w wodzie pozwala na zachowanie naturalnej zielonej barwy charakterystycznej dla warzywa świeżego. Utrata intensywności barwy zielonej związana jest z degradacją chlorofilu i powstawaniem feofityny w wyniku zastąpienia jonu $\mathrm{Mg}^{+}$przez $\mathrm{H}^{+}$w pierścieniu porfirynowym. Z kolei Zhong i wsp. [33] wykazali, że barwa brokułu gotowanego mikrofalowo w wodzie lub parowanego staje się bardziej żółta, podczas gdy tego zjawiska nie obserwuje się w czasie mikrofalowania brokułu zapakowanego w rękaw (steamable bag), co jest techniką zbliżoną do metody sous-vide.

Cechy sensoryczne, takie jak: barwa, zapach, wygląd, atrakcyjne opakowanie są pierwszymi atrybutami produktu, na które konsument zwraca uwagę podczas podejmowania decyzji o zakupie artykułu spożywczego. Ocena tekstury produktu następuje najczęściej dopiero $\mathrm{w}$ trakcie spożywania żywności, niemniej jednak odgrywa ona równie istotną rolę. Tekstura warzyw analizowanych na talerzu, zarówno parowanych, jak i gotowanych metodą sous-vide była wysoko oceniona, niższe oceny tego parametru przyznano warzywom gotowanym tradycyjnie $(\mathrm{p}<0,05)$. Wyjątek stanowił kalafior, bowiem lepszą teksturą odznaczało się warzywo gotowane w wodzie niż przygotowane metodą sous-vide. Odmienne wyniki uzyskali Mansour i wsp. [17]. Autorzy ci wykazali, że tekstura kalafiora poddanego tradycyjnej obróbce hydrotermicznej była niżej oceniana niż na przykład przygotowanego z wykorzystaniem mikrofal. Jednocześnie badacze potwierdzili, że parowanie brokułu jest korzystną formą obróbki w kontekście nie tylko zachowania właściwego zapachu, ale także tekstury. Wysoka temperatura indukuje zmiękczenie tkanek, co w konsekwencji ułatwia żucie. Odpowiednia tekstura warzyw gotowanych istotna jest $\mathrm{z}$ uwagi na ich akceptację nie tylko przez osoby dorosłe, ale także, a może przede wszystkim, przez dzieci. Poelman i wsp. [26] w badaniach z udziałem dzieci w wieku 5 - 6 lat stwierdzili, że bardziej akceptowane przez nie są warzywa twardsze, chrupiące, dlatego też preferują one raczej te surowe niż gotowane. Analiza wyników dotyczących oceny poszczególnych parametrów tekstury, takich jak twardość i wilgotność pozwala zauważyć, że najwięcej ocen pozytywnych przyznano warzywom parowanym. W przypadku kruchości warzyw (z wyjątkiem kalafiora) najkorzystniejsze było natomiast ich tradycyjne gotowanie w wodzie. Gotowanie na parze wymaga najczęściej dłuższego czasu obróbki niż gotowanie tradycyjne w wodzie w celu uzyskania zbliżonej tekstury. Podobnie jest w przypadku przygotowania warzyw metodą sous-vide, ponieważ obniżenie temperatury powoduje automatycznie wydłużenie czasu obróbki $[10,20]$. Jednocześnie należy podkreślić, że zastosowanie metody sous-vide, podobnie jak gotowanie pod zwiększonym ciśnieniem, skutkuje większą soczystością warzyw, czemu sprzyja wcześniejsze ich zapakowanie [18]. Guillen i wsp. [12] nie wykazali zróżnicowania twardości brokułu w zależności 
od metody obróbki (gotowanie tradycyjne przez $12 \mathrm{~min}$, gotowanie sous-vide przez $17 \mathrm{~min})$.

Brukselka, kalafior typu Romanesco i kalafior o róży białej przygotowane metodą sous-vide odznaczały się właściwym zapachem, odpowiednio dla [\%]: 78,6, 64,3, 64,3 oceniających. Niżej oceniono zapach warzyw gotowanych tradycyjnie. Ponadto w przypadku kalafiora o róży białej, zdaniem 14,1 \% oceniających, warzywo gotowane tradycyjnie odznaczało się niewłaściwym lub obcym zapachem. Takiej sytuacji nie stwierdzono w przypadku pozostałych warzyw czy technik kulinarnych. Poelman i wsp. [26] wykazali, że zapach brokułu i kalafiora parowanego jest wyżej oceniany niż gotowanego tradycyjnie. Zdaniem Martinez-Hernandez i wsp. [18] gotowanie tradycyjne pozwala natomiast na uzyskanie istotnie lepszego zapachu brokułu niż ich parowanie. Jednocześnie autorzy nie wykazali istotnych różnic $\mathrm{w}$ ocenie tego parametru pomiędzy gotowaniem $w$ wodzie a metodą sous-vide.

W przypadku smaku warzyw w zależności od formy obróbki termicznej nie wykazano jednoznacznych tendencji. Właściwa słoność to cecha sensoryczna najczęściej wskazywana w przypadku warzyw gotowanych w niższej temperaturze po zapakowaniu próżniowym (niezależnie od ich rodzaju) w porównaniu z warzywami poddawanymi innym technikom kulinarnym. Było to wynikiem ochronnego wpływu wcześniejszego pakowania, które zabezpieczało warzywa przed bezpośrednim kontaktem ze środowiskiem wodnym. Brak istotnych różnic smaku brokułów w zależności od metody obróbki stwierdzili Martinez-Hernandez i wsp. [18]. Taki sam wniosek sformułowali Mansour i wsp. [17] w odniesieniu do kalafiora. Iborra-Bernad i wsp. [14] z kolei wskazują, że technika sous-vide pozwala na uzyskanie lepszego smaku kapusty czerwonej w porównaniu z jej tradycyjnym gotowaniem.

$\mathrm{Na}$ podstawie instrumentalnego pomiaru barwy i obliczonej całkowitej różnicy barw $(\Delta \mathrm{E})$ wykazano, że barwa warzyw przygotowanych metodą sous-vide (za wyjątkiem kalafiora) była najbardziej zbliżona do barwy warzyw surowych (tab. 3).

Jednocześnie największą zmianę barwy (w stosunku do surowca) odnotowano w przypadku gotowania w wodzie brokułu, kalafiora typu Romanesco i brukselki, co było zapewne związane z niekorzystnymi przemianami chlorofilu. Jak wskazują Greve i wsp. [11] oraz Heaton i Marangoni [13], wysoka temperatura stosowana podczas obróbki hydrotermicznej warzyw zielonych powoduje degradację pigmentów chlorofilowych oraz deformację strukturalną tkanek roślinnych, co sprzyja stopniowemu pogarszaniu się konsystencji produktu. W przypadku kalafiora o róży białej i brokułu wszystkie zastosowane metody obróbki spowodowały w stosunku do surowca istotne obniżenie wartości parametru L*. Wyniki te są zbieżne z rezultatami otrzymanymi przez dos Reisa i wsp. [4], którzy stwierdzili, że każdy rodzaj obróbki termicznej (gotowanie, parowanie, sous-vide, mikrofalowanie) kalafiora i brokułu powoduje istotne $(\mathrm{p}<0,05)$ obniżenie wartości tego parametru. 
Tabela 3. Wyniki pomiarów składowych barwy w systemie CIE L*a*b*

Table 3. Results of measured colour parameters in CIE L*a*b*system

\begin{tabular}{|c|c|c|c|c|c|}
\hline $\begin{array}{l}\text { Warzywa } \\
\text { Vegetables }\end{array}$ & $\begin{array}{l}\text { Proces termiczny } \\
\text { Thermal process }\end{array}$ & $\mathrm{L}^{*}$ & $a^{*}$ & $\mathrm{~b}^{*}$ & $\Delta \mathrm{E}$ \\
\hline \multirow{4}{*}{$\begin{array}{l}\text { Kalafior biały } \\
\text { Cauliflower }\end{array}$} & Surowy / Raw & $66,89^{\mathrm{c}} \pm 2,92$ & $3,94^{\mathrm{c}} \pm 0,66$ & $13,40^{\mathrm{c}} \pm 0,37$ & - \\
\hline & $\begin{array}{l}\text { Gotowanie w wodzie } \\
\text { Cooking in water }\end{array}$ & $41,36^{\mathrm{a}} \pm 1,89$ & $0,18^{\mathrm{a}} \pm 0,39$ & $11,17^{\mathrm{a}} \pm 0,92$ & 16,13 \\
\hline & $\begin{array}{l}\text { Gotowanie na parze } \\
\text { Steaming }\end{array}$ & $45,72^{\mathrm{b}} \pm 5,14$ & $0,44^{\mathrm{b}} \pm 0,35$ & $13,15^{\mathrm{b}} \pm 0,33$ & 21,46 \\
\hline & $\begin{array}{l}\text { Gotowanie sous-vide } \\
\text { Sous-vide cooking }\end{array}$ & $48,65^{\mathrm{b}} \pm 5,13$ & $0,65^{\mathrm{b}} \pm 0,26$ & $10,03^{\mathrm{a}} \pm 0,31$ & 18,83 \\
\hline \multirow{4}{*}{$\begin{array}{l}\text { Brokuł } \\
\text { Broccoli }\end{array}$} & Surowy / Raw & $21,07^{\mathrm{d}} \pm 0,08$ & $0,85^{\mathrm{a}} \pm 1,04$ & $8,97^{\mathrm{a}} \pm 1,76$ & - \\
\hline & $\begin{array}{l}\text { Gotowanie w wodzie } \\
\text { Cooking in water }\end{array}$ & $13,00^{\mathrm{a}} \pm 1,05$ & $1,42^{\mathrm{bc}} \pm 0,65$ & $10,23^{\mathrm{a}} \pm 1,89$ & 8,48 \\
\hline & $\begin{array}{l}\text { Gotowanie na parze } \\
\text { Steaming }\end{array}$ & $18,89^{\mathrm{c}} \pm 0,99$ & $1,21^{\mathrm{b}} \pm 1,24$ & $14,40^{\mathrm{b}} \pm 0,84$ & 5,86 \\
\hline & $\begin{array}{l}\text { Gotowanie sous-vide } \\
\text { Sous-vide cooking }\end{array}$ & $16,86^{\mathrm{b}} \pm 0,81$ & $2,32^{\mathrm{c}} \pm 0,08$ & $10,03^{\mathrm{a}} \pm 1,27$ & 4,58 \\
\hline \multirow{4}{*}{$\begin{array}{l}\text { Kalafior typu } \\
\text { Romanesco } \\
\text { Romanesco } \\
\text { cauliflower }\end{array}$} & Surowy / Raw & $31,72^{b} \pm 6,34$ & $-1,13^{a} \pm 0,30$ & $27,70^{\mathrm{b}} \pm 0,81$ & - \\
\hline & $\begin{array}{l}\text { Gotowanie w wodzie } \\
\text { Cooking in water }\end{array}$ & $19,59^{\mathrm{a}} \pm 1,71$ & $-1,16^{\mathrm{a}} \pm 0,28$ & $28,10^{\mathrm{b}} \pm 0,49$ & 15,47 \\
\hline & $\begin{array}{c}\text { Gotowanie na parze } \\
\text { Steaming }\end{array}$ & $32,11^{\mathrm{b}} \pm 0,86$ & $1,67^{\mathrm{c}} \pm 0,38$ & $22,25^{\mathrm{a}} \pm 0,21$ & 11,39 \\
\hline & $\begin{array}{l}\text { Gotowanie sous-vide } \\
\text { Sous-vide cooking }\end{array}$ & $30,91^{b} \pm 1,06$ & $0,64^{\mathrm{b}} \pm 0,14$ & $29,60^{\mathrm{b}} \pm 0,49$ & 9,55 \\
\hline \multirow{4}{*}{$\begin{array}{c}\text { Brukselka } \\
\text { Brussels sprouts }\end{array}$} & Surowy / Raw & $25,18^{\mathrm{b}} \pm 1,26$ & $-5,02^{\mathrm{a}} \pm 1,07$ & $16,71^{\mathrm{c}} \pm 0,06$ & - \\
\hline & $\begin{array}{l}\text { Gotowanie w wodzie } \\
\text { Cooking in water }\end{array}$ & $20,01^{\mathrm{a}} \pm 0,75$ & $-4,59^{\mathrm{a}} \pm 0,56$ & $11,00^{\mathrm{a}} \pm 0,83$ & 16,21 \\
\hline & $\begin{array}{l}\text { Gotowanie na parze } \\
\text { Steaming } \\
\end{array}$ & $29,77^{\mathrm{c}} \pm 1,41$ & $1,18^{\mathrm{b}} \pm 0,14$ & $13,62^{\mathrm{b}} \pm 0,33$ & 8,79 \\
\hline & $\begin{array}{l}\text { Gotowanie sous-vide } \\
\text { Sous-vide cooking }\end{array}$ & $27,60^{\mathrm{b}} \pm 1,97$ & $2,77^{\mathrm{c}} \pm 0,57$ & $20,36^{\mathrm{d}} \pm 2,69$ & 8,94 \\
\hline
\end{tabular}

Objaśnienia / Explanatory notes:

W tabeli przedstawiono wartości średnie \pm odchylenia standardowe / Table shows mean values \pm standard deviation; $\mathrm{a}, \mathrm{b}, \mathrm{c}$ - wartości średnie oznaczone różnymi literami różną się statystycznie istotnie $(\mathrm{p} \leq 0,05)$ / mean values denoted by different letters differ statistically significantly $(\mathrm{p} \leq 0.05)$.

\section{Wnioski}

1. Na podstawie wyników uzyskanych metodą skalowania przy użyciu skali 5-punktowej nie wykazano istotnego zróżnicowania jakości sensorycznej warzyw w zależności od metody ich obróbki termicznej.

2. Rezultaty oceny jakości z wykorzystaniem 9-stopniowej skali hedonicznej są potwierdzeniem, że przygotowanie do spożycia kalafiora, brokułu oraz brukselki poprzez ich parowanie i gotowanie metodą sous-vide pozwala na uzyskanie warzyw o wyższej jakości sensorycznej niż po ich tradycyjnym gotowaniu w wodzie. Po- 
dobne wyniki w przypadku obróbki termicznej brokułu uzyskano po zastosowaniu metody szeregowania.

3. Przeprowadzona ocena metodą opisową profilowania sensorycznego z wykorzystaniem skali ustrukturowanej umożliwiła wykazanie, że tekstura zarówno warzyw gotowanych metodą sous-vide, jak i parowanych była wyżej oceniana niż gotowanych tradycyjnie.

4. Na podstawie instrumentalnego pomiaru barwy i obliczonej wartości $\Delta \mathrm{E}$ wykazano, że barwa warzyw przygotowanych metodą sous-vide była najbardziej zbliżona do barwy warzyw surowych.

5. Zastosowane metody badawcze nie pozwoliły na jednoznaczną ocenę przydatności poszczególnych technik obróbki hydrotermicznej warzyw.

\section{Literatura}

[1] Bere E., Klepp K.I.: Changes in accessibility and preferences predict children's future fruit and vegetable intake. Int. J. Behav. Nutr. Phys. Act., 2005, 2 (1), \#15.

[2] Baldwin D.E.: Sous vide cooking: A review. I. J. G. F. S., 2012, 1, 15-30.

[3] Bi J.: Sensory discrimination tests and measurements statistical principles, procedures and tables. Blackwell Publishing Professional, Iowa, USA 2006.

[4] Dos Reis L.C.R., de Oliveira V.R., Hagen M.E.K., Jablonski A., Flôres S.H., de Oliveira Rios A.: Carotenoids, flavonoids, chlorophylls, phenolic compounds and antioxidant activity in fresh and cooked broccoli (Brassica oleracea var. Avenger) and cauliflower (Brassica oleracea var. Alphina F1). LWT - Food Sci. Technol., 2015, 63, 177-183.

[5] Drewnowski A., Gomez-Carneros C.: Bitter taste, phytonutrients, and the consumer: A review. Am. J. Clin. Nutr., 2000, 72(6), 1424-1435.

[6] Cox D.N., Melo L., Zabaras D., Delahunty C.M.: Acceptance of health-promoting Brassica vegetables: The influence of taste perception, information and attitudes. Public Health Nutr., 2012, 15 (8), 1474-1482.

[7] Engel E., Baty C., le Corre D., Souchon I., Martin N.: Flavor-active compounds potentially implicated in cooked cauliflower acceptance. J. Agric. Food Chem., 2002, 50 (22), 6459-6467.

[8] Florkiewicz A., Ciska E., Filipiak-Florkiewicz A., Topolska K.: Comparison of sous-vide methods and traditional hydrothermal treatment on GLS content in Brassica vegetables. Eur. Food Res. Technol., 2017, 243 (9), 1507-1517.

[9] Florkiewicz A., Berski W.: Application of sous vide method as an alternative to traditional vegetable cooking to maximize the retention of minerals. J. Food Process. Preserv., 2018, 42, \#13508, 1-9.

[10] Galgano F., Favati F., Caruso M., Pietrafesa A., Natella S.: The influence of processing and preservation on the retention of health-promoting compounds in broccoli. J. Food Sci., 2007, 72 (2), S130S135.

[11] Greve L.C., Shackel K.A., Ahmadi H., McArdle R.N., Gohlke J.M., Labavitch, J.M.: Impact of heating on carrot firmness: Contribution of cellular Turgor. J. Agric. Food Chem., 1994, 42, 28962899.

[12] Guillén S., Mir-Bel J., Oria R., Salvador M.L.: Influence of cooking conditions on organoleptic and health-related properties of artichokes, green beans, broccoli and carrots. Food Chem., 2017, 217, 209-216. 
[13] Heaton J.W., Marangoni A.G.: Chlorophyll degradation in processed foods and senescent plant tissues. Trends Food Sci. Technol., 1996, 7, 8-15.

[14] Iborra-Bernad C., Tárrega A., García-Segovia P., Martínez-Monzó J.: Advantages of sous-vide cooked red cabbage: Structural, nutritional and sensory aspects. LWT - Food Sci. Technol., 2014, $56,2,451-460$.

[15] ISO 8587:2006. Sensory analysis. Methodology. Ranking.

[16] Kala A., Prakash J.: The comparative evaluation of the nutrient composition and sensory attributes of four vegetables cooked by different methods. Int. J. Food Sci. Technol., 2006, 41, 163-171.

[17] Mansour A.A., Elshimy N.M., Shekib L.A., Sharara M.S.: Effect of domestic processing methods on the chemical composition and organoleptic properties of broccoli and cauliflower. Am. J. Food Nutr., 2015, 3 (5), 125-130.

[18] Martínez-Hernández G.B., Artés-Hernández F., Colares-Souza F., Gómez P.A., García-Gómez P., Artés F.: Innovative cooking techniques for improving the overall quality of a kailan-hybrid broccoli. Food Bioprocess. Technol., 2013, 6, 2135-2149.

[19] Nunn M.D., Giraud D.W., Parkhurst A.M., Hamouz F.L., Driskell J.A.: Effects of cooking methods on sensory qualities and carotenoid retention in selected vegetables. J. Food Quality, 2006, 29, 445457.

[20] Pellegrini N., Chiavaro E., Gardana C., Mazzeo T., Contino D., Gallo M., Riso P., Fogliano V., Porrini M.: Effect of different cooking methods on color, phytochemical concentration, and antioxidant capacity of raw and frozen Brassica vegetables. J. Agric. Food Chem., 2010, 58(7), 4310-4321.

[21] PN-ISO 3972:1998. Analiza sensoryczna. Metodologia. Metoda sprawdzania wrażliwości smakowej.

[22] PN-EN ISO 8589:2010. Analiza sensoryczna. Ogólne wytyczne dotyczące projektowania pracowni analizy sensorycznej.

[23] PN-ISO 4121:1998. Analiza sensoryczna. Metodologia. Ocena produktów żywnościowych przy użyciu metod skalowania.

[24] PN-EN ISO 13299:2016-05. Analiza sensoryczna. Metodyka. Ogólne wytyczne ustalania profilu sensorycznego.

[25] Poelman A.A.M., Delahunty C.M.: The effect of preparation method and typicality of colour on children's acceptance for vegetables. Food Qual. Prefer., 2011, 22 (4), 355-364.

[26] Poelman A.A.M., Delahunty C.M., de Graaf C.: Cooking time but not cooking method affects children's acceptance of Brassica vegetables. Food Qual. Prefer., 2013, 28, 441-448.

[27] Rasmussen M., Krølner R., Klepp K.-I., Lytle L., Brug J., Bere E., Due P.: Determinants of fruit and vegetable consumption among children and adolescents: A review of the literature. Part I: Quantitative studies. Int. J. Behav. Nutr. Phys. Act., 2006, 3 (1), \#22.

[28] Silva D.J.: Nutritional quality and health benefits of vegetables: A review. Food Nutr. Sci., 2012, 3, 1354-1374.

[29] Song L., Thornalley P.J.: Effect of storage, processing and cooking on glucosinolate content of Brassica vegetables. Food Chem. Toxicol., 2007, 45 (2), 216-224.

[30] Steiner J.E.: Human facial expressions in response to taste and smell stimulation. Advances in Child Development and Behavior, 1979, 13, 257-295.

[31] Wardle J., Huon G.: An experimental investigation of the influence of health information on children's taste preferences. Health Educ. Res., 2000, 15 (1), 39-44.

[32] Yuan G., Sun B., Yuan J., Wang Q.: Effects of different cooking methods on health-promoting compounds of broccoli. J. Zhejiang Univ. Sci. B, 2009, 10 (8), 580-588.

[33] Zhong X., Dolan K.D., Almenar E.: Effect of steamable bag microwaving versus traditional cooking methods on nutritional preservation and physical properties of frozen vegetables: A case study on broccoli (Brassica oleracea). Innov. Food Sci. Emerg., 2015, 31, 116-122. 


\title{
SENSORY QUALITY OF BRASSICA VEGETABLES PROCESSED USING SOUS-VIDE AND TRADITIONAL HYDROTHERMAL TECHNIQUES
}

\author{
S u m m a r y
}

Sensory properties of cruciferous vegetables are a substantial determinant for consumers. The distinctive bitter flavour of those vegetables results mainly from the occurrence of glucosinolates therein and it is considered a major impediment to consumer acceptance. It is known however, that the method of preparing them for consumption can have a significant effect on their sensory properties.

The objective of the paper was the sensory evaluation of four common species of Brassica vegetables, such as broccoli, cauliflower with white rose, Romanesco cauliflower, Brussels sprouts, which underwent diverse hydrothermal treatments (traditional cooking, steaming, sous-vide technique). Immediately after the thermal treatment the vegetables were sensorily evaluated using the following methods: scaling (5-point method and 9-point hedonic scale), preference rating and descriptive sensory profiling with the use of a structured scale. Additionally an instrumental measurement of vegetables' colours was carried out. Based on the scaling evaluation results obtained using of a 5-point scale, no significant thermal treatment dependent variations were reported in the sensory properties under analysis. Based on the results of sensory evaluation with the use of 9-point hedonic scale, it was found that the steamed and sous-vide cooked cauliflower, broccoli and Brussels sprouts were characterized by a higher sensory quality than that of the traditionally water-cooked vegetables. The evaluation carried out using a descriptive sensory profiling with a structured scale showed that the texture of both the sous-vide cooked vegetables and the steamed vegetables was rated higher than that of the traditionally cooked vegetables. The results of the instrumental colour measurement and the value of $\Delta \mathrm{E}$ computed on the basis thereof showed that the colour of vegetables prepared using the sous-vide method was as close as possible to the colour of raw vegetables.

Key words: cruciferous vegetables, sous-vide, steaming, cooking in water, sensory quality 